\title{
Evaluation of the protective effect of Red Ginseng on lipid profile, endothelial and oxidative damage after splenectomy in rats
}

\author{
Ratlarda splenektomi sonrası Red Ginseng'in lipit profili, endotel ve oksidatif hasar üzerinde koruyucu \\ etkisinin değerlendirilmesi
}

\author{
Koray Koşmaz ${ }^{1}$, Abdullah Durhan ${ }^{1}$, Abdullah Şenlikçii ${ }^{1}$ Marlen Süleyman ${ }^{1}$, Mustafa Taner Bostancı ${ }^{2}$, Mevlüt Recep \\ Pekçici $^{1}$, Mehmet Şeneş ${ }^{3}$, İlknur Alkan Kuşabbi ${ }^{3}$, Mehmet Alparslan Gönültaş ${ }^{4}$, Sema Hücümenoğlu ${ }^{4}$, Aziz Mutlu Barlas ${ }^{1}$, \\ Yusuf Murat Bağ ${ }^{5}$, Can Ersak ${ }^{1}$, Ender Ergüder ${ }^{1}$
}

\section{Abstract}

Aim: It was aimed to examine the effects of Red Ginseng (RG), which has anti-inflammatory and antioxidant properties, on the histopathological alterations and lipid metabolism following splenectomy.

Methods: Rats were randomly divided into 3 groups of 10 rats each. Only laparotomy was conducted in group 1 (sham). In group 2 (control), splenectomy was performed but no therapy was offered. Splenectomy was performed and RG extract was supplied orogastrically at a dosage of $100 \mathrm{mg} / \mathrm{kg} /$ day for 28 days in group 3 ( $\mathrm{RG}$ group). At the end of the 28 -day period, tissue samples were obtained for the assessment of histopathological alterations in the vascular, intestinal, and lung tissues, and blood samples were obtained for biochemical analysis.

Results: The RG group had reduced significantly total cholesterol (TC), triglyceride (TG), and very low density lipoprotein (VLDL) levels than the control group ( $\mathrm{p}<0.05$ ). When mononuclear cell infiltration in colon and lung tissues was evaluated, it was shown to be considerably lower in the RG group $(\mathrm{p}<0.05)$. For aortic tissues, there was no difference between the groups. Malondialdehyde (MDA) levels were observed to be considerably lower in the RG group compared to the control group ( $\mathrm{p}$ $<0.05$ ). The total sulfhydryl (t-SH) level increased considerably in the RG group as compared to the control group. ( $\mathrm{p}<0.05$ ) Conclusions: After splenectomy, RG usage decreases oxidative stress in mice. It has also been demonstrated to have a regulating impact on lipid metabolism. Furthermore, the administration of RG following splenectomy was found to have a poor likelihood of improving vascular, lung, and colon epithelial regeneration.

Keywords: Splenectomy, Red ginseng, lipid profile, antioxidant.

\section{Öz}

Amaç: Anti-inflamatuar ve antioksidan etkili red ginsegin splenektomi sonrası görülen histopatolojik değişiklikler ve lipid profili üzerindeki etkisi araştırıldı.

Yöntemler: Sıçanlar rastgele her biri 10 sıçandan olușan 3 gruba ayrıldı. Grup 1'de (sham), sadece laparotomi yapıldı. Grup 2'de (kontrol), splenektomi uygulandı fakat ek hiçbir tedavi uygulanmadı. Grup 3'te (Red ginseng grubu), splenektomi yapıldı ve Red Ginseng (RG) ekstresi orogastrik yoldan $100 \mathrm{mg} / \mathrm{kg} /$ gün doz olarak 28 gün süreyle uygulandı. 28 günün sonunda vasküler, intestinal ve akciğer dokularındaki histopatolojik değişiklikler incelemesi için doku örnekleri alındı ve biyokimyasa analiz için kan örnekleri alındı.

Bulgular: Total kolestrol (TC), trigliserit (TG) ve çok düşük yoğunluklu lipoprotein (VLDL) düzeyleri kontrol grubuna göre RG grubunda anlamlı olarak azalmıştır $(\mathrm{p}<0,05)$. Kolon ve akciğer dokusundaki mononükleer hücre infiltrasyonunun RG grubunda kontrol grubuna göre anlamlı derecede azaldığı görüldü $(\mathrm{p}<0,05)$. Aort dokusunda hiç bir grup arasında fark saptanmadı Malondialdehit (MDA) seviyelerinin de RG grubunda kontrol grubuna göre anlamlı derecede azaldığı görüldü ( $<<0,05)$. Tota sülfhidril (t-SH) seviyesinin ise RG grubunda kontrol grubuna göre anlamlı derecede artış gösterdiği saptandı $(\mathrm{p}<0,05)$.

Sonuç: RG kullanımı splenektomi yapılan ratlarda oksidatif stresi azaltmakta ve lipid metabolizması üzerinde düzenleyici etk göstermektedir. Bununla birlikte RG kullanımının splenektomi sonrası ortaya çıkan vasküler, akciğer ve kolon epitelindek rejenerasyonu artırıcı etkisi gözlenmemiştir.

Anahtar Kelimeler: Splenektomi, Red ginseng, lipid profili, antioksidan.
${ }^{1}$ University of Health Sciences, Ankara Education and Research Hospital, Department of General Surgery, Ankara, Turkey.

${ }^{2}$ University of Health Sciences, Dıș Kapı Yıldırım Beyazit Education and Research Hospital, Department of General Surgery, Ankara, Turkey.

${ }^{3}$ University of Health Sciences, Ankara Education and Research Hospital, Department of Biochemist, Ankara, Turkey.

${ }^{4}$ University of Health Sciences, Ankara Education and Research Hospital, Department of Medical Pathology, Ankara, Turkey.

${ }^{5}$ University of Health Sciences, Van Education and Research Hospital, Department of General Surgery, Ankara, Turkey.

Ethics Committee Approval: This study was approved by the Ankara Education and Research Hospital Animal Experiments Local Ethics Comittee (16.04.2021- 0065:661).

Etik Kurul Onayı: Bu çalışma için Ankara Eğitim ve Araştırma Hastanesi Hayvan Deneyleri Yerel Etik Kurulu'ndan onay alınmıştır (16.04.20210065:661).

Conflict of Interest: No conflict of interest was declared by the authors.

Çıkar Çatışması: Yazar çıkar çatışması bildirmemiştir.

Financial Disclosure: The authors declared that this case has received no financial support.

Finansal Destek: Yazarlar bu çalışma için finansal destek almadıklarını beyan etmişlerdir.

Geliș Tarihi / Received: 15.06.2021

Kabul Tarihi / Accepted: 30.07.2021

Yayın Tarihi / Published: 02.08.2021

Sorumlu yazar / Corresponding author:

Koray Koşmaz

Adres/Address: Ankara Eğitim ve Araştırma Hastanesi Genel Cerrahi Kliniği A blok 1 kat Hacettepe Mah, Ulucanlar Cad, No:87, Altındağ, Ankara, Turkey.

e-mail: koraykosmaz@hotmail.com

Tel/Phone: 00905065362371

Copyright (C) ACEM 


\section{Introduction}

Today, the most common reason for splenectomy is trauma. Furthermore, splenectomy is performed in response to a variety of etiological reasons, including hematological and primary spleen disorders. Hematological consequences of splenectomy include leukocytosis and thrombocytosis $[1,2]$. The spleen also plays a significant role in lipid metabolism and works as a lipid reservoir, according to research conducted in humans and rats, and as a result, hyperlipidemia is seen in many cases following splenectomy [3, 4]. The filtration of aberrant and aged erythrocytes by activated macrophages is another crucial function of the spleen [5]. Because the phagocytosis function is lost in splenectomy patients, the number of injured cells in the bloodstream rises, vascular homeostasis is disrupted, and the coagulation system is activated, resulting in vascular problems [2]. Pulmonary hypertension is one of the most common diseases linked with vascular problems after splenectomy [1].

In today's world, Panax ginseng is one of the most often utilized herbal remedies in both Asian and Western countries. Ginseng is a succulent perennial herb that grows slowly. Red ginseng $(\mathrm{RG})$ is the most important sub-component of this plant root, which is made up of ginsoids. RG; It has been used in traditional medicine for many years, particularly in far eastern countries like Korea and Japan, and its effects are still being investigated in many studies. It is used in many fields of medicine, including liver, cardiovascular disease, kidney disease, autoimmune systemic diseases, various malignancies, and immune system strengthening [6-8]. According to research, RG regulates the activity of inflammatory signaling pathways, which have anti-inflammatory properties in inflammatory responses [9]. Although several animal research has demonstrated the possible influence of RG on blood lipid profiles, there is not enough research to evaluate the lipid profile after splenectomy $[10,11]$.

In this study, we examined the histopathological changes in vascular, intestinal, and respiratory tissues after splenectomy and the possible effects of RG on these changes.

\section{Material and methods}

The experimental procedures and technique of this study met the requirements of the National Guidelines for the Use and Care of Laboratory Animals, and the Animal Ethics Committee approved this study (approval date: 16.04.2021, issue 0065:661). All transactions were carried out by adhering to ethical rules and principles.

\section{Animals and experimental-surgical procedures}

The study sample consisted of 30 female adult Wistar albino rats, each weighing $230 \pm 22 \mathrm{~g}$. Rats have housed in wire mesh cages at a sustained temperature of $21 \pm 2{ }^{\circ} \mathrm{C}$ with a 12 hour light/dark cycle. The animals had a diet consisting of standard laboratory food and as much water as they wanted. For rats, access to food was stopped 12 hours before anesthesia and access to water 2 hours before anesthesia. The same team performed anesthesia and surgical intervention under sterile conditions. Before intervention procedures, $50 \mathrm{mg} / \mathrm{kg}$ ketamine hydrochloride (Ketalar; Parke-Davis, Detroit, MI, USA) and 5 $\mathrm{mg} / \mathrm{kg}$ Xylazine (Rompun; Bayer AG, Leverkusen, Germany) were anesthetized via intramuscular injection. Rats were randomly divided into 3 groups of 10 rats: sham group, control group, and treatment group. In group 1 (sham), the only laparotomy was performed. In group 2 (control), the spleen peduncle was ligated with $4 / 0$ silk and splenectomy was performed In group 3 (RG group), spleen peduncle was ligated with 4/0 silk, splenectomy was performed, then RG [ Korean 6Year Root Red Ginseng Extract (Samsung, Korea)] was administered with the help of an orogastric tube at a dose of 100 $\mathrm{mg} / \mathrm{kg} /$ day for 28 days. After the aforementioned procedures were completed, the abdominal incisions were closed in two continuous layers with $3 / 0$ silk sutures in all three groups. The rats were allowed to feed after surgery. All animals were euthanized after 28 days using an overdose of ketamine. After laparotomy and sternotomy, 4-5 cc blood samples were taken for biochemical analysis of lipid profile, platelet, leukocytes, antioxidant parameters, and oxidative stress markers. Aortic segment, $8 \mathrm{~cm}$ distal segments of the total colectomy specimen, and lung tissue samples were taken for histopathological examination.

In the Ankara Training and Research Hospital Medical Biochemistry Department, white blood cell (WBC), hemogram, lipid profiles, malondialdehyde (MDA), and total sulfhydryl ( $\mathrm{t}$ $\mathrm{SH}$ ) in serum were assessed. On the day the samples were obtained, lipid profiles and hemograms were taken. Serum samples were stored at $-80^{\circ} \mathrm{C}$ until analysis day for the determination of MDA and t-SH. Hemogram measurements were performed on the Sysmex XN-Series instrument. Total cholesterol (TC), low-density lipoprotein cholesterol (LDL-C), high-density lipoprotein cholesterol (HDL-C), triglyceride (TG) measurements in serum were made using Roche Cobas 8000 biochemistry analyzer using Roche Cobas commercial kits for clinical purposes. Very low density lipoprotein (VLDL) values were calculated by total cholesterol-(HDL-C) + LDL-C) formula. The levels of MDA were determined using the fluorometric approach, as described by Wasowicz et al. [12]. The reaction product of thiobarbituric acid (TBA) and MDA was separated in butanol following the reaction. Then, at a wavelength of $547 \mathrm{~nm}$ for emission and $525 \mathrm{~nm}$ for excitation, a spectrofluorometrical measurement was performed. The standard was a solution of $1,1^{\prime}, 3,3^{\prime}$ tetra ethoxy propane ranging from 0 to $5 \mathrm{~mol} / \mathrm{L}$. To assess MDA levels in tissue, $50 \mathrm{~mL}$ serum was placed in $10 \mathrm{ml}$ glass tubes, each with $1 \mathrm{ml}$ distilled water. The acetic acid was then combined with a $1 \mathrm{~mL}$ solution containing $29 \mathrm{mmol} / \mathrm{L}$ TBA. Following that, the samples were placed in a water bath and exposed to heat between $95^{\circ}$ and $100^{\circ} \mathrm{C}$ for 1 hour. After cooling the heated samples, they were mixed with 25 liters of $5 \mathrm{~mol} / \mathrm{L}$ hydrochloric acids (HCL) and agitated for 5 minutes to extract the reaction mixture using $3.5 \mathrm{~mL}$-butanol. A fluorometer (HITACHI F-2500) was used to measure the fluorescence in the butanol extract at $547 \mathrm{~nm}$ and $525 \mathrm{~nm}$ wavelengths for emission and excitation, respectively, after the butanol phase was separated by centrifugation for 10 minutes at $1500 \mathrm{~g}$. MDA concentrations were expressed in milligrams per liter $(\mathrm{mol} / \mathrm{L})$. The principle described by Taylan et al. was used to perform the t-SH measurement by adapting the Ellman reaction to the microplate method, they were able to use this method [13]. The study utilized a methanolic 5,5'-dithiobis (2-nitrobenzoic acid) (DTNB) solution that reacts with sulfhydryl groups. A multimeasurement mode microplate reader with a monochromator was used to measure the reaction products. The measurement was carried out at $412 \mathrm{~nm} .200 \mu \mathrm{L}$ of Tris buffer $(0.25 \mathrm{M}$ Tris$\mathrm{HCl}, \mathrm{pH} 8.2$ containing $20 \mathrm{mM}$ EDTA) was pipetted and $25 \mu \mathrm{L}$ of homogenate was added. $10 \mu \mathrm{L}$ of DTNB reagent $(4 \mathrm{mg} / \mathrm{mL}$ in methanol) was added to each well and incubated for 15 minutes at room temperature, then the absorbance of yellow 5thio-2-nitrobenzoic acid (TNB) at $412 \mathrm{~nm}$ (A2) was measured against blank (A1). The same settings were used to test glutathione standards, and the curve was created using linear regression analysis. The standard curve developed using reduced 
glutathione (GSH) (between 0 and $450 \mathrm{M}$ ) was used to calculate the quantity of the t-SH group in the samples according to the net absorbance (A2-A1) mol/L is the unit of measurement for $\mathrm{t}-\mathrm{SH}$ levels.

\section{Histopathological analysis}

Samples were obtained after all tissues were preserved with $10 \%$ neutral formalin. Tissues were traced using an automatic tissue tracking system, and subsequently, paraffinembedded blocks were obtained. Hematoxylin and eosin were used to stain the blocks, which were sliced into $6 \mathrm{~mm}$ thick slices (H\&E). The histopathologist assessed all samples without definition under a light microscope (Nikon Optiphat-2). Oculometrically, the wall thickness of the aorta tissue was assessed. The presence and absence of calcification in the artery wall, mononuclear cell infiltration, foamy macrophages, and fatty streaks findings were also assessed. Saverymuttu et al. developed a technique for evaluating intestine biopsy samples, which was followed [14]. Changes in enterocytes, crypts, and lamina propria were scored in this table, and a total value between 0 and 12 was assigned to each sample. The presence and absence of lymphoid nodules and alveolar degeneration were investigated in lung tissue, and the presence of mononuclear cells and polymorphonuclear leukocytes were graded independently between 0 and 3 values. It was given a score of 0 (none), 1 (mild), 2 (moderate), and 3 (severe) based on previous research (severe) (Table 1).

Table 1. Histopathological scoring of the intestinal tissue samples.

Cells/Regions $\quad$ Findings $\quad$ Grade

$\begin{array}{llr}\text { Enterocytes } & \text { Normal } & 0 \\ & \text { Loss of single cells } & 1 \\ & \text { Loss of groups of cells } & 2 \\ & \text { Frank ulceration } & 3 \\ \text { Mononuclear cells in LP } & \text { Normal } & \\ & \text { Slight increase } & 0 \\ & \text { Moderate increase } & 1 \\ & \text { Marked increase } & 2 \\ & & 3 \\ \text { Neutrophils in LP } & \text { Normal } & 0 \\ & \text { Slight increase } & 1 \\ & \text { Moderate increase } & 2 \\ & \text { Marked increase } & 3 \\ & & \\ \text { Crypts } & \text { Normal } & 0 \\ & \text { Single inflammatory cells } & 1 \\ & \text { Cryptitis } & 2 \\ & \text { Cryptic abscesses } & 3\end{array}$

\begin{tabular}{lc}
\hline Total & 12 \\
\hline LP: Lamina propria
\end{tabular}

\section{Statistical Analysis}

The Shapiro-Wilk test was used to assess the normality of the distribution of continuous variables. Normally distributed continuous variables were given as mean \pm standard deviation and were compared using the one-way analysis of variance (ANOVA) test followed by Tukey's honestly significant difference (HSD) post hoc test. Non-normally distributed continuous variables were described as median (minimummaximum) and were compared using the Kruskal-Wallis test followed by Mann-Whitney U multiple comparison test. A P value $<0.05$ was considered significant. Statistical analyses were performed using the IBM SPSS Statistics for Windows, version 25.0 (IBM Corp., Armonk, N.Y., USA).

\section{Results}

Throughout the trial, one rat from the Sham group, two rats from the control group, and two rats from the $\mathrm{RG}$ group died after surgery, and no further issues were identified. Table 2 shows the results and comparisons of serum lipid profile and hematological parameters. The control group had the highest mean TC level, with significant disparities between it and the other groups. Furthermore, there was no significant difference in TC levels between the sham and RG groups.

The levels of HDL and LDL were not substantially different between the groups. The control group had much greater TG levels than the other groups, and the difference between the control and RG groups was substantial. When the TG levels of the Sham and RG groups were examined, there was no significant difference. VLDL levels differed significantly between the control and other groups, with the control group having the highest levels. When the VLDL levels of the Sham and RG groups were examined, there was no significant difference. PTL and WBC levels were found to be significantly higher in the control group compared to the sham group. When the control group and the RG group were compared, there was a decrease in WBC and PTL counts, but there was no statistically significant difference between these two groups. Table 3 summarizes MDA and total SH levels. The control group showed the highest median MDA level. There were significant differences in median MDA values between the control group and the other groups $(\mathrm{p}=0.009$, and $\mathrm{p}=0.039)$. A sham group measured the highest median total SH level. The differences in median total $\mathrm{SH}$ levels between the control group and the other groups were likewise significant $(p=0.002$ and $p=0.012$, respectively), similar to the differences in median MDA levels.

Table 4 shows the histopathological scores of the tissue samples. A large difference was seen in the mononuclear cell infiltration score in the colon samples. The highest score was seen in the control group, and the lowest score was in the sham group. The differences were significant in all comparisons. The cryptid was significantly higher in the control group than in the sham group, but there was no significant difference when compared with the RG group. Enterocyte damage was seen at a higher rate in the control group than in the sham and RG groups, but it was not statistically significant (Figure 1).

Table 2. Results and comparisons of serum lipid profile and hematological parameters.

\begin{tabular}{lcccccc} 
& $\begin{array}{c}\text { Sham group } \\
\text { (Group 1) }\end{array}$ & $\begin{array}{c}\text { Control } \\
\text { group } \\
\text { (Group 2) }\end{array}$ & $\begin{array}{c}\text { RG } \\
\text { group } \\
\text { (Group 3) }\end{array}$ & $\begin{array}{c}\text { P } \\
\text { value } \\
(2-3)\end{array}$ & $\begin{array}{c}\text { P } \\
\text { value } \\
(1-2)\end{array}$ & $\begin{array}{c}\text { P } \\
\text { value } \\
(1-3)\end{array}$ \\
\hline $\begin{array}{l}\text { TC } \\
(\mathrm{mg} / \mathrm{dL})\end{array}$ & $47.33 \pm 6.61$ & $58.75 \pm 12.24$ & $48.87 \pm 13.72$ & 0.006 & 0.010 & 0.994 \\
$\begin{array}{l}\mathrm{HDL} \\
(\mathrm{mg} / \mathrm{dL})\end{array}$ & $31.55 \pm 5.14$ & $30.85 \pm 9.89$ & $31.30 \pm 10.86$ & 0.868 & 0.985 & 0.860 \\
$\begin{array}{l}\mathrm{LDL} \\
(\mathrm{mg} / \mathrm{dL})\end{array}$ & $5.84 \pm 1.75$ & $7.62 \pm 2.64$ & $6.57 \pm 1.92$ & 0.165 & 0.220 & 0.238 \\
$\begin{array}{l}\mathrm{TG} \\
(\mathrm{mg} / \mathrm{dL})\end{array}$ & $36(16-96)$ & $79(30-155)$ & $40.5(26-80)$ & 0.021 & 0.014 & 0.834 \\
$\begin{array}{l}\mathrm{VLDL} \\
(\mathrm{mg} / \mathrm{dL})\end{array}$ & $9.5(2.5-15.8)$ & $19.5(7-54.4)$ & $10.25(0.9-25.6)$ & 0.005 & 0.003 & 0.962 \\
$\begin{array}{l}\mathrm{WBC} \\
\left(\mathrm{x} 10^{3} / \mathrm{uL}\right)\end{array}$ & $6.32 \pm 1.15$ & $9.80 \pm 3.25$ & $8.81 \pm 2.57$ & 0.006 & 0.020 & 0.010 \\
$\begin{array}{l}\mathrm{PLT} \\
\left(\mathrm{x} 10^{3} / \mathrm{lL}\right)\end{array}$ & $357.62 \pm 196.43$ & $753.12 \pm 207.39$ & $688.44 \pm 146.25$ & 0.001 & 0.001 & 0.021 \\
\hline
\end{tabular}

RG: Red ginseng TC: Total cholesterol, HDL: High-density lipoprotein, LDL: Low-density lipoprotein, TG: Triglycerides, VLDL: Very-low-density lipoprotein, WBC: White blood cell, PLT: Platelet

Table 3. Results and comparisons of malondialdehyde and total sulfhydryl levels in blood.

\begin{tabular}{lcccccc} 
& $\begin{array}{c}\text { Sham } \\
\text { group } \\
\text { (Group 1) }\end{array}$ & $\begin{array}{c}\text { Control } \\
\text { group } \\
\text { (Group 2) }\end{array}$ & $\begin{array}{c}\text { RG } \\
\text { group } \\
\text { (Group 3) }\end{array}$ & $\begin{array}{c}\mathrm{P} \\
\text { value } \\
(2-3)\end{array}$ & $\begin{array}{c}\mathrm{P} \\
\text { value } \\
(1-2)\end{array}$ & $\begin{array}{c}\mathrm{P} \\
\text { value } \\
(1-3)\end{array}$ \\
\hline MDA & 0.15 & 0.21 & 0.17 & 0.010 & 0.009 & 0.086 \\
(micromol/L) & $(0.14-0.23)$ & $(0.18-0.4)$ & $(0.15-0.26)$ & & & \\
Total SH & $280.50 \pm$ & $221.40 \pm$ & $271.49 \pm$ & 0.002 & 0.002 & 0.828 \\
(micromol/L) & 22.48 & 37.33 & 34.05 & & & \\
\hline
\end{tabular}


Table 4. Results and comparisons of histopathological scores of tissue samples

\begin{tabular}{|c|c|c|c|c|c|c|}
\hline & $\begin{array}{c}\text { Sham } \\
\text { group } \\
\text { (Group 1) }\end{array}$ & $\begin{array}{c}\text { Control } \\
\text { group } \\
\text { (Group 2) }\end{array}$ & $\begin{array}{c}\text { RG } \\
\text { group } \\
\text { (Group 3) }\end{array}$ & $\begin{array}{c}P \\
\text { value } \\
(2-3)\end{array}$ & $\begin{array}{c}\mathrm{P} \\
\text { value } \\
(1-2) \\
\end{array}$ & $\begin{array}{c}\mathrm{P} \\
\text { value } \\
(1-3) \\
\end{array}$ \\
\hline \multicolumn{7}{|c|}{ Colon } \\
\hline $\begin{array}{l}\text { Enterocyte } \\
\text { damage }\end{array}$ & $0(0-0)$ & $0(0-2)$ & $0(0-1)$ & 0.555 & 0.289 & 0.289 \\
\hline $\begin{array}{l}\text { Mononuclear } \\
\text { cell infiltration }\end{array}$ & $0(0-0)$ & $1(1-2)$ & $1(0-1)$ & $<0.001$ & $<0.001$ & 0.002 \\
\hline $\begin{array}{l}\text { Neutrophils } \\
\text { infiltration }\end{array}$ & $0(0-1)$ & $0.5(0-1)$ & $0.5(0-1)$ & 0.163 & 0.088 & 0.088 \\
\hline Cryptitis & $0(0-0)$ & $0.5(0-2)$ & $0(0-1)$ & 0.056 & 0.020 & 0.050 \\
\hline \multicolumn{7}{|c|}{ Lung } \\
\hline $\begin{array}{l}\text { Lymphoid } \\
\text { follicle }\end{array}$ & $0(0-1)$ & $1.5(1-3)$ & $1(1-2)$ & 0.003 & 0.004 & 0.009 \\
\hline $\begin{array}{l}\text { Alveolar } \\
\text { degeneration }\end{array}$ & $2(0-2)$ & $2.5(2-3)$ & $2(1-3)$ & 0.027 & 0.012 & 0.300 \\
\hline $\begin{array}{l}\text { Mononuclear } \\
\text { cell infiltration }\end{array}$ & $1(1-2)$ & $2.5(2-3)$ & $2(1-2)$ & 0.012 & 0.012 & 0.514 \\
\hline $\begin{array}{l}\text { Neutrophils } \\
\text { infiltration }\end{array}$ & $0(0-1)$ & $1(0-2)$ & $1(0-1)$ & 0.039 & 0.020 & 0.102 \\
\hline \multicolumn{7}{|c|}{ Aorta } \\
\hline Aortic diameter & $\begin{array}{c}190 \\
(100-200)\end{array}$ & $\begin{array}{c}205.5 \\
(150-280)\end{array}$ & $\begin{array}{c}200 \\
(100-201)\end{array}$ & 0.246 & 0.119 & 0.414 \\
\hline $\begin{array}{l}\text { Neutrophils } \\
\text { infiltration }\end{array}$ & $0(0-0)$ & $0(0-0)$ & $0(0-0)$ & - & - & - \\
\hline $\begin{array}{l}\text { Macrophage } \\
\text { infiltration }\end{array}$ & $0(0-0)$ & $0(0-0)$ & $0(0-0)$ & - & - & - \\
\hline Fatty streak & $0(0-0)$ & $0(0-0)$ & $0(0-0)$ & - & - & - \\
\hline
\end{tabular}

\section{RG: Red ginseng}
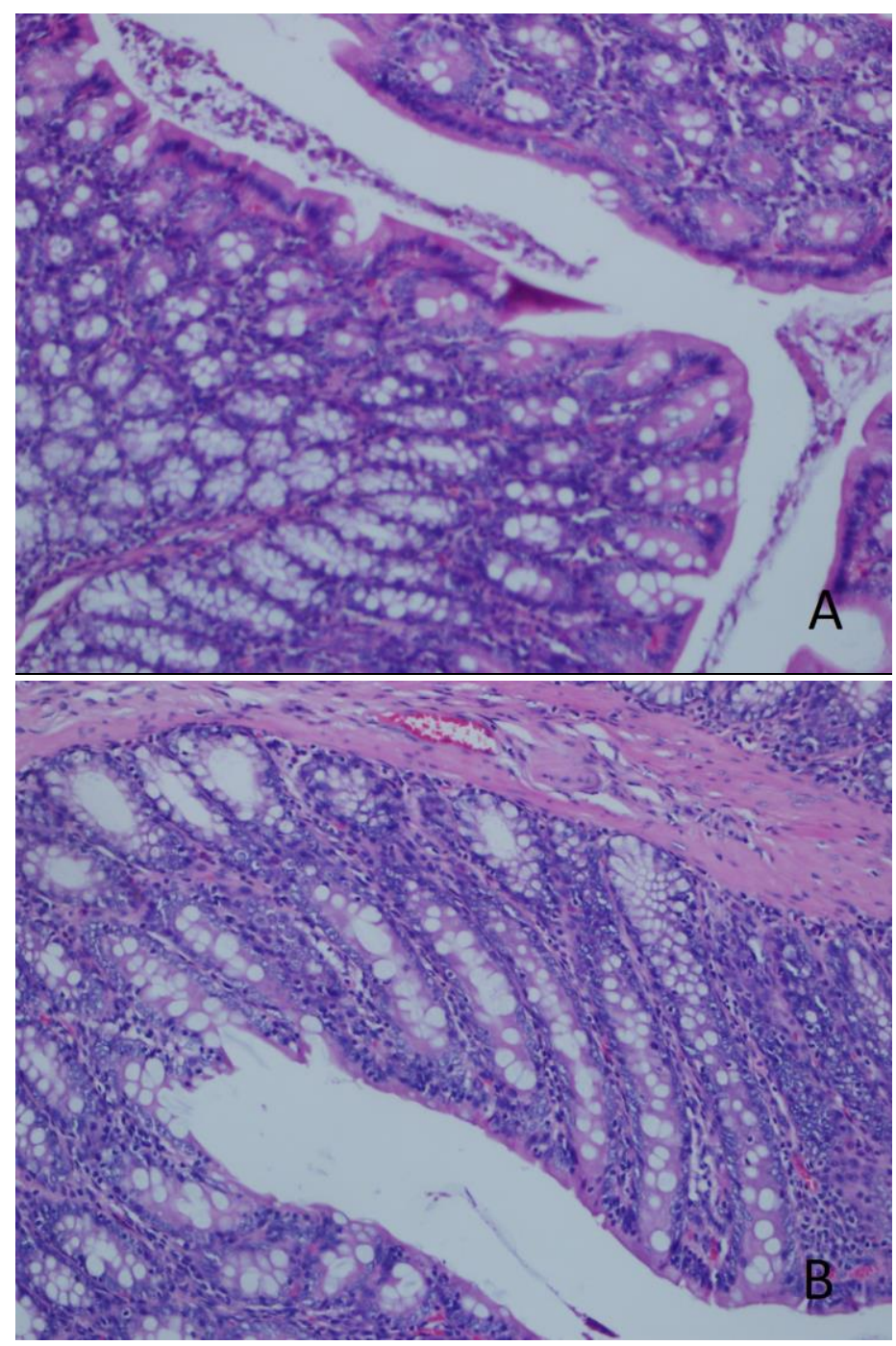

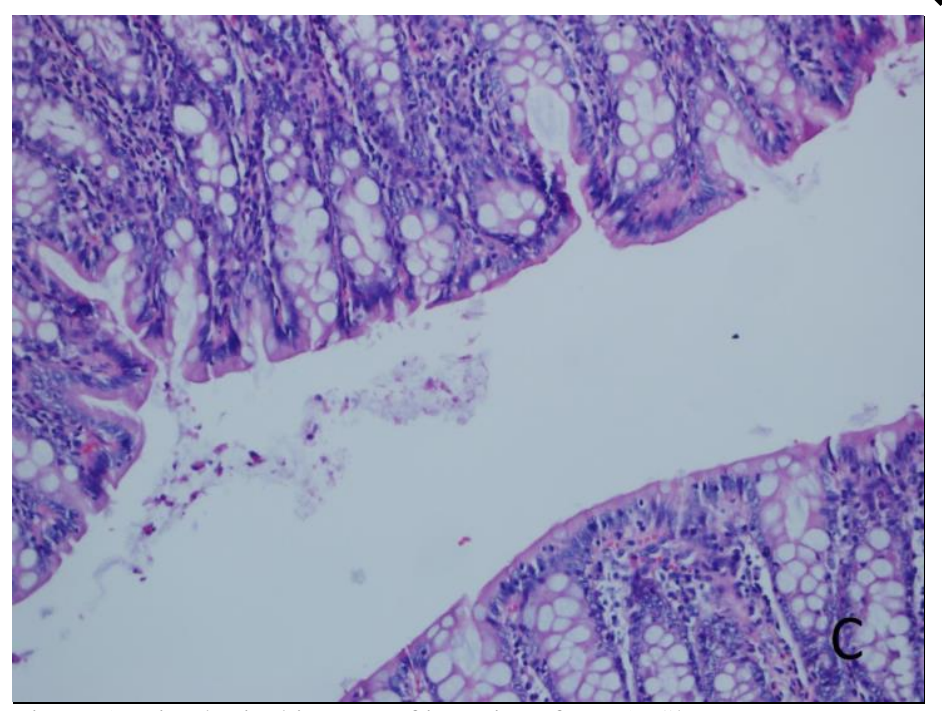

Figure 1: Histological images of intestines from A. Sham group B.

Control group C. Red Ginseng group.

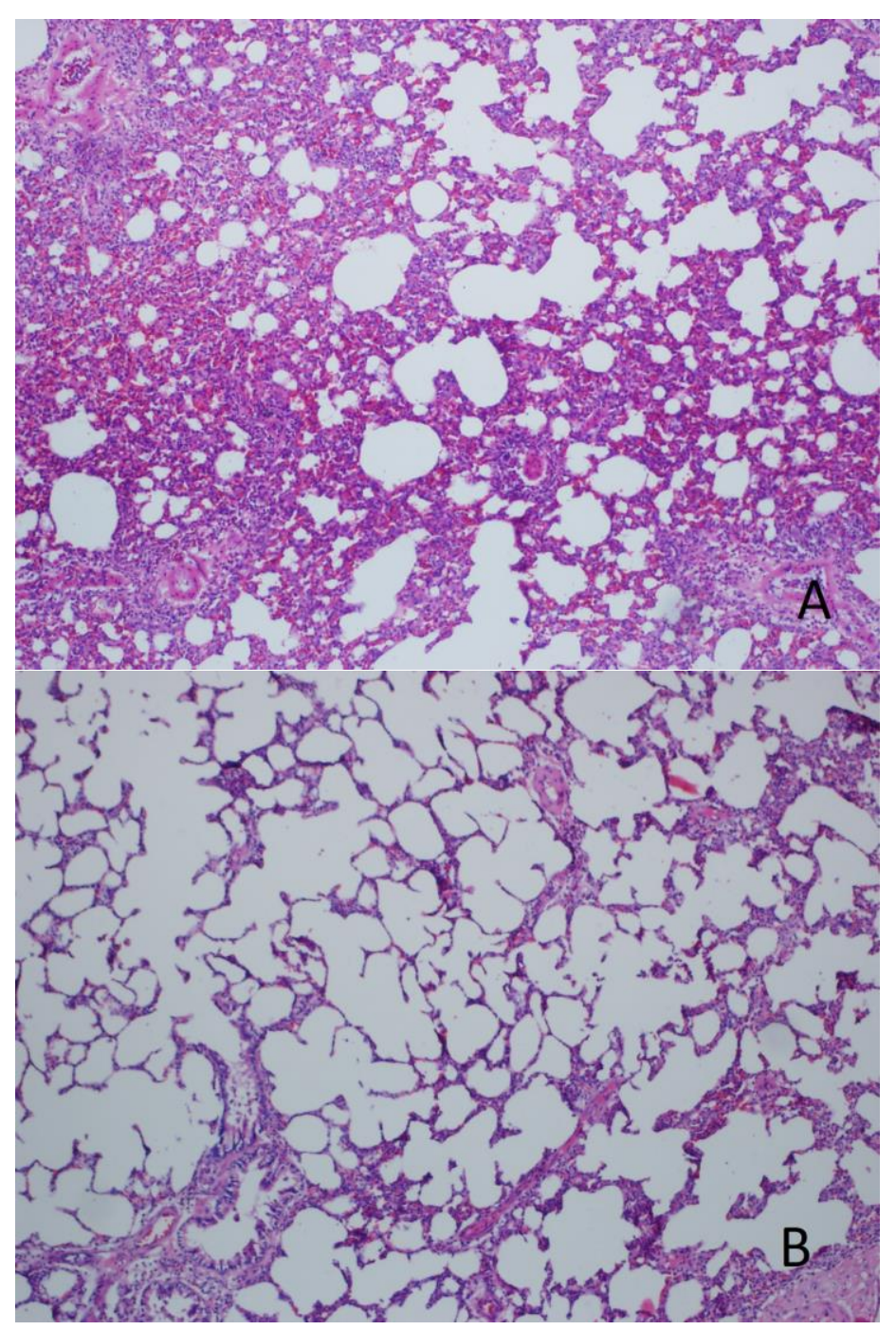






Figure 2: Histological images of lung tissues from A. Sham group B. Control group C. Red Ginseng group.

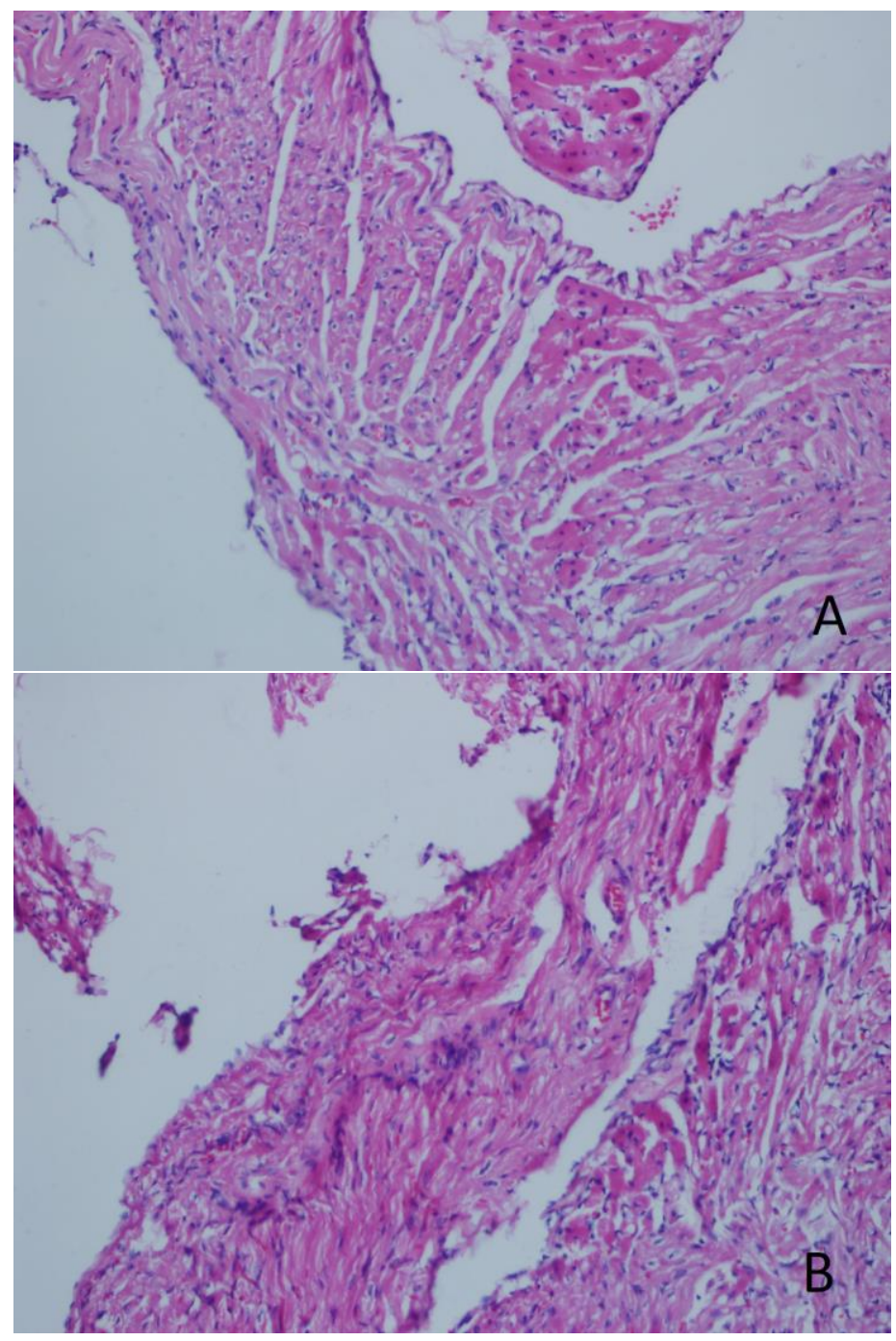



Figure 3: Histological images of aorts of rats from A. Sham group B. Control group C. Red Ginseng group.

The control group and the other groups had significantly different mononuclear cell infiltration scores in lung tissue samples, but there was no significant difference between the RG group and the sham group. There were significant differences in the lymphoid follicle, alveolar degeneration, and neutrophil infiltration ratings between the control and sham groups, but none between the control and the RG group (Figure 2 ). The aortic diameter measurements were not significantly different between the groups, and there was no evidence of neutrophil or macrophage infiltration or fatty streak in any of the samples (Figure 3).

\section{Discussion}

This is the first study to examine the effect of RG use on histopathological changes in vascular, lung, and colon tissue after differential splenectomy. Because of its immunological function, much recent information has been distributed on the need of attempting to protect the spleen during elective or emergency surgical procedures. Many researchers have prompted them to work toward total splenectomy in cases where it is unavoidable in order to avoid problems and metabolic alterations [15]. The relevance of splenic tissue as a key regulator of immunological and hematopoietic activities cannot be overstated today [16]. Well-designed studies have revealed that the spleen has a significant influence on lipid metabolism [17] Many theories have been presented to explain the possible mechanism, the majority of which are based on strong innate immune activity, specifically the mononuclear phagocytic system, however, the exact processes underlying this mysterious phenomena remain unknown. safeguards While the incidence of atherosclerosis (AS) was higher in individuals who had a splenectomy after a splenic injury, the incidence of AS did not change in instances with conservative follow-up [18]. After splenectomy, vascular and systematic hemostasis due to damaged erythrocytes or thrombocytosis is damaged and causes serious systemic complications such as pulmonary hypertension [1].

In this study, we first evaluated the histopathological changes in endothelial, alveolar, and vascular tissues after splenectomy in rats, as well as their effects on lipid profile and antioxidant mechanisms. Second, we focused on the therapeutic effects of RG, a well-known antioxidant and anti-inflammatory agent, on the lipid profile, respiratory, gastrointestinal, and vascular systems. Panax ginseng is one of the most widely used herbal remedies in Asian and Western countries. Ginseng is a slow-growing, succulent perennial herb, the root of which is 
composed of ginsenosides and the most important subcomponent is red ginseng (RG). Panax ginseng has many bioactive elements such as triterpene saponins, polysaccharides, sesquiterpenes, polyacetylenes, amino acids, fatty acids, carbohydrates, alkaloids, peptidoglycans, minor elements, vitamins, and phenolic compounds [19-20]. Numerous research has demonstrated the effects of RG, including immune system activation, pharmacological effects on the endocrine and cardiovascular systems, anti-cancer, antioxidant, cognitive performance enhancement, and aging deferral. Obesity, diabetes, and hyperlipidemia are just a few of the metabolic disorders linked with aging that have historically been treated with RG [21-24]. Furthermore, the administration of RG dramatically reduces visceral adipocyte hypertrophy, which is linked to metabolic disorders such as insulin resistance and hepatic steatosis. In the study of Lee et al., RG has shown that dietinduced and ovariectomized obese mice reduce adipose tissue mass and prevent obesity [25-26]. After total splenectomy in rats, they noticed a rise in plasma cholesterol levels, indicating the spleen's role in lipid metabolism [27]. In another rat study, TG, HDL-C, and VLDL levels increased, although LDL-C levels decreased when compared to rats that underwent total splenectomy and were all fed with standard feed and underwent only laparotomy [28]. The spleen may also influence lipid metabolism in the gut by triggering inflammatory processes and oxidative stress, leading to lower lipid peroxidation after splenectomy [29]. Increased TC, TG, and VLDL plasma levels in splenectomy rats considerably lowered TC, TG, and VLDL levels compared to the control group in our investigation, indicating that RG has a therapeutic effect on lipid metabolism. In addition, in the biochemical analysis of serum lipid profile in our study, there was no difference between the groups in HDL and LDL levels. This may be a result of impaired macrophage functions and changes in lipoprotein metabolism after splenectomy [30]. The number of mononuclear cells in the intestinal tissue of the splenectomy rats was considerably larger than in the sham and RG groups, according to our histological analyses. When the RG group was compared to the control group, however, there was decreased mononuclear cell infiltration in the RG group, which was statistically significant. This discovery shows that RG has an anti-inflammatory effect on splenectomy rats' intestinal tissue. Erythrocyte damage was found to be higher in splenectomy rats and enterocyte damage was observed to be less compared to the RG group, but there was no statistically significant difference. Cryptitis was found to be significantly higher in the splenectomy group compared to the sham group, but although cryptitis was less common in the RG group than in the control group, it was not statistically significant.

Vascular complications and related pulmonary hypertension may occur after splenectomy [1]. In addition, Andres-Hernando et al. reported that splenectomy exacerbated lung damage and inflammatory reactions in their study on rats. In the study of Cho et al., they showed that the use of RG reduced lung damage due to the use of ventilators [32]. Therefore, we examined the vascular and respiratory changes and possible effects of RG after splenectomy in rats. Lymphoid follicle, alveolar degeneration, mononuclear cell infiltration, and neutrophil infiltration scores were found to be significantly higher in splenectomized rats compared to the sham group. In the RG group, compared to the control group, there was a statistically significant decrease in mononuclear cell infiltration. Although there was a decrease in the lymphoid follicle, alveolar degeneration, and neutrophil infiltration scores in the RG group compared to the control group, it was not statistically significant. When the aortic diameters of the sham and control groups were compared, an increase in aortic diameters was observed in the control group, but it was not statistically significant. In addition, when the RG group was compared with the control group, aortic diameters were decreased, but it was not statistically significant. Neutrophil infiltration, macrophage infiltration, and fatty streaking were not observed in any of the groups. Durhan et al. created a mechanical icterus model in rats and demonstrated the anti-inflammatory and antioxidant effects of RG. In their study, they showed that RG significantly decreased MDA values, which indicates intracellular oxidative stress, and significantly increased the level of catalase, which is an important antioxidant [31]. Another study showing the antioxidant effect of RG is the study of Cho et al. They showed that the use of RG in lung injury caused by mechanical ventilation in rats significantly decreased MDA values [32]. In our study, the MDA level, which indicates intracellular oxidative stress, increased significantly in splenectomy rats compared to the sham group. When the RG group and the control group were compared, MDA values were found to be significantly decreased. Total $\mathrm{SH}$ values, which is an antioxidant parameter, decreased in the control group and increased significantly in the RG group. Especially platelet and leukocyte values of 113 patients who underwent splenectomy were found to be significantly higher when compared with healthy individuals without a specific disease [33]. In another study on rats, leukocyte and thrombocyte levels were found to be significantly higher in the splenectomy group compared to the control group [28]. In our study, a significant increase was observed in platelet and WBC counts after splenectomy compared to the sham group, in line with many studies in the literature. However, although there was a decrease in platelet and WBC counts in the RG group, this decrease was not statistically significant.

In conclusion, the use of RG after splenectomy in rats has been shown to have a significant anti-inflammatory effect by reducing mononuclear cell infiltration within the histopathological changes occurring in the lungs and colon tissue. However, the probability of improving epithelial regeneration was low. It was observed that the use of RG was significantly effective on rats in the regulation of the antioxidant system and lipid profile, which deteriorated after splenectomy. While promising beneficial effects of RG have been demonstrated, more clinical studies are needed to apply these positive results in clinical settings.

\section{References}

1. Crary SE, Buchanan GR. Vascular complications after splenectomy for hematologic disorders. Blood. 2009;114:286168.

2. Taher A, Isma'eel H, Mehio G, Bignamini D, Kattamis A, Rachmilewitz EA, et al. Prevalence of thromboembolic events among 8,860 patients with thalassaemia major and intermedia in the Mediterranean area and Iran. Thromb Haemost. 2006;96:48891.

3. Paulo DN, Paulo IC, Morais AA, Kalil M, Guerra AJ, Colnago GL, et al. Is splenectomy a dyslipidemic intervention? Experimental response of serum lipids to different diets and operations. Microsurgery. 2009;29:154-60.

4. Temiz C, Solmaz I, Tehli O, Kaya S, Onguru O, Arslan E, et al. The effects of splenectomy on lipid peroxidation and neuronal loss in experimental spinal cord ischemia/reperfusion injury. Turk Neurosurg. 2013;23:67-74.

5. Tuchscherer D, Reinhart WH. What is the spleen needed for ? Ther Umsch. 2013;70:147-51.

6. Ahuja A, Kim JH, Kim JH, Yi YS, Cho JY. Functional role of ginseng-derived compounds in cancer. Journal of ginseng research. 2018;42:248-54.

7. Huu TN, Uto T, Morinaga O, Kim YH, Shoyama Y Pharmacological effects of ginseng on liver functions and 
diseases: A minireview. Evidence-based complementary and alternative medicine: Evid Based Complement Alternat Med. 2012;2012:173297.

8. Abdelfattah-Hassan A, Shalaby SI, Khater SI, El-Shetry ES, Abd El Fadil H, Elsayed SA. Panax ginseng is superior to vitamin E as a hepatoprotector against cyclophosphamide-induced liver damage. Complement Ther Med. 2019;46:95-102.

9. Kim JH, Yi YS, Kim MY, Cho JY. Role of ginsenosides, the main active components of Panax ginseng, in inflammatory responses and diseases. J Ginseng Res. 2017;41:435-43.

10. Park Y, Kwon H, Shimi MK, Rhyu M, Lee Y. Improved lipid profile in ovariectomized rats by red ginseng extract Pharmazie. 2011;66:450-3.

11. Shin S S, Yoon M. Korean red ginseng (Panax ginseng) inhibits obesity and improves lipid metabolism in high fat diet-fed castrated mice. J Ethnopharmacol. 2018;210:80-87.

12. Wasowicz W, Nève J, Peretz A. Optimized steps in fluorometric determination of thiobarbituric acid-reactive substances in serum: importance of extraction $\mathrm{pH}$ and influence of sample preservation and storage. Clin Chem. 1993;39:2522-6.

13. Taylan E, Resmi H. The Analytical Performance of a Microplate Method for Total Sulfhydryl Measurement in Biological Samples. Turk J Biochem. 2010;35;275-8.

14. Saverymuttu SH, Camilleri M, Rees H, Lavender JP, Hodgson HJ, Chadwick VS. Indium 111-granulocyte scanning in the assessment of disease extent and disease activity in inflammatory bowel disease. A comparison with colonoscopy, histology, and fecal indium 111-granulocyte excretion. Gastroenterology. 1986 May;90(5 Pt 1):1121-8.

15. Miko I, Nemeth N, Sipka S Jr, Brath E, Peto K, GulyasA, Furka I, et al. Hemorheological follow-up after splenectomy and spleen autotransplantation in mice. Microsurgery. 2006;26:38-42.

16. Simões FC, Marques RG, Diestel CF, Caetano CER, Dinis APG, Horst NL, et al. Lipidic profile among rats submited to total splenectomy isolated or combined with splenic autotransplant. Acta Cir Bras. 2007;22:46-51.

17. Caligiuri G, Nicoletti A, Poirier B, Hansson GK. Protective immunity against atherosclerosis carried by $\mathrm{B}$ cells of hypercolesterolemic mice. J Clin Invest. 2002;109:745-53.

18. Ai XM, Ho LC, Han LL, Lu JJ, Yue X, Yang NY. The role of splenectomy in lipid metabolism and atherosclerosis. Lipids Health Dis. 2018;17:186.

19. Ahuja A, Kim JH, Kim JH, Yi YS, Cho JY. Functional role of ginseng-derived compounds in cancer. J Ginseng Res. 2018;42:248-54.

20. YZ Xiang, H.C. Shang, XM Gao, BL Zhang, A comparison of the ancient use of ginseng in traditional Chinese medicine with modern pharmacological experiments and clinical trials. Phytother Res. 2008;22:851-8.

21. T Ramesh, SW Kim, SY Hwang, SH Sohn, SK Yoo, SK Kim, Panax ginseng reduces oxidative stress and restores antioxidant capacity in aged rats, Nut. Res. 2012;32:718-26.

22. EH Park, YJ Kim, N Yamabe, SH Park, HK Kim, HJ Jang, et al. Stereospecific anticancer effects of ginsenoside $\mathrm{Rg} 3$ epimers isolated from heat-processed American ginseng on human gastric cancer cell, J. Gins. Res. 2014;38;22-7.

23. YJ Kim, N Yamabe, P Choi, JW Lee, J Ham, KS Kang, Efficient thermal deglycosylation of ginsenoside Rd and its contribution to the improved anticancer activity of ginseng. J Agric Food Chem. 2013;61:9185-91.

24. Yin J, Zhang H, Ye J. Traditional Chinese medicine in treatment of metabolic syndrome. Endocr Metab Immune Disord Drug Targets. 2008;8:99-111.

25. Lee M, Sung SH. Platyphylloside isolated from Betula platyphylla inhibit adipocyte differentiation and induce lipolysis via regulating adipokines including PPAR $\gamma$ in 3T3-L1 cells. Pharmacogn Mag. 2016;12:276-81.

26. 25.Lee H, Kim M, Shin SS, Yoon M. Ginseng treatment reverses obesity and related disorders by inhibiting angiogenesis in female $\mathrm{db} / \mathrm{db}$ mice. J Ethnopharmacol. 2014;155:1342-52.

27. Salomao-Paulo DN, Lazaro-da-Silva A. The plasma lipids after total and partial splenectomy in dogs. Rev Col Bras Cir. 2001;28:264-70

28. Sit M, Yilmaz EE, Tosun M, Aktas G. Effects of N acetyl cysteine on lipid levels and on leukocyte and platelet count in rats after splenectomy. Niger J Clin Pract. 2014;17:343-5.
29. Ai XM, Ho LC, Han LL, Lu JJ, Yue X, Yang NY. The role of splenectomy in lipid metabolism and atherosclerosis (AS). Lipids Health Dis. 2018;17:186.

30. Temiz C, Solmaz I, Tehli O, Kaya S, Arslan E, Izci Y, et al. The effects of splenectomy on lipid peroxidation and neuronal loss in experimental spinal cord ischemia/reperfusion injury. Turk Neurosurg. 2013;23:67-74.

31. Durhan A, Koşmaz K, Şenlikci A, Ergüder E, Süleyman M, Duymuş ME, et al. Does red ginseng ameliorate liver damage caused by obstructive jaundice?: An experimental study. J Health Sci Med. 2021;4:233-9.

32. Cho WH, Kim YH, Heo HJ, Kim D, Kwak TW, Kim KH, et al. Ginsenoside ameliorated ventilator-induced lung injury in rats. J Intensive Care. 2020;23;8:89.

33. Rab MAE, Meerveld-Eggink A, van Velzen-Blad H, van Loon D, Rijkers GT, de Weerdt O. Persistent changes in circulating white blood cell populations after splenectomy Int $\mathrm{J}$ Hematol. 2018;107:157-65. 